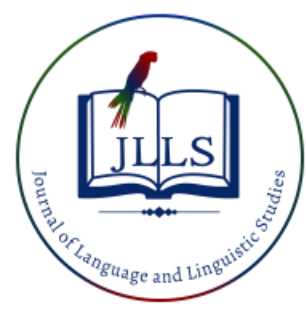

Available online at www.jlls.org

JOURNAL OF LANGUAGE AND LINGUISTIC STUDIES

ISSN: $1305-578 \mathrm{X}$

Journal of Language and Linguistic Studies, 16(4), 2097-2112; 2020

\title{
Being a teacher in the English language-oriented course
}

\author{
Özge Bakay a iD, Özlem Saka ${ }^{1}$ b iD \\ ${ }^{a}$ Ministry of National Education, Antalya, Turkey \\ ${ }^{b}$ Akdeniz University, Antalya, Turkey
}

\section{APA Citation:}

Bakay, Ö. \& Saka, Ö. (2020). Being a teacher in an English language-oriented course. Journal of Language and Linguistic Studies, 16(4), 2097-2112.

Submission Date:13/10/2020

Acceptance Date:24/11/2020

\begin{abstract}
The English language-oriented course (ELOC) corresponds to the $11^{\text {th }}$ and $12^{\text {th }}$ grades of high school and are highly preferred by students. Yet, the implementation of ELOC's curriculum is an issue that is hardly focused on in the field. Although the curriculum developed for all $11^{\text {th }}$ and $12^{\text {th }}$-grade students by the Ministry of National Education is comprehensively planned, there seem to be some challenges teachers face while implementing it due to its irrelevancy to ELOC. In the present study, it is aimed to reveal how the implemented curriculum is perceived by teachers. The research group includes 31 English teachers from Anatolian high schools in Antalya that have ELOC. The study adopted a qualitative research design. The data were collected from teachers via semi-structured interviews, administered by the researchers, and then examined by utilizing content analysis. The major areas of investigation consist of the teachers' opinions of the overall curriculum implementation, coursebooks, and teaching methods used. In-depth data about this matter are revealed. At the end of the study, an understanding of how the the curriculum of English language-oriented course was being applied was established. It was concluded that almost none of the teachers were satisfied with overall curriculum implementation, coursebooks, and the teaching methods preferred. Many of the teachers pointed out that the university entrance examination directly impacts on teaching methods and curriculum, which also results in disfavour of coursebooks. In consideration of the results of the study, some suggestions were proposed covering the issues of curriculum, coursebook, and teaching methods.
\end{abstract}

(C) 2020 JLLS and the Authors - Published by JLLS.

Keywords: English language curriculum; English language teaching; ELOC coursebooks; teaching methods; challenges faced in English language-oriented course; problems of English teachers of ELOC

\section{Introduction}

As the use of mass media becomes widespread and easier with each passing day in the globalizing world, political, social, cultural, and commercial relations have gained another dimension among communities. Therefore, the need for learning the language of other nations has emerged as a result of these multidimensional relations. Becoming a common language tool all over the world, English is the most economical way of meeting through this need (Taşl1, 2003). Thus, the field of English Language

\footnotetext{
${ }^{1}$ Corresponding author.

E-mail address: ozlemsaka@akdeniz.edu.tr
} 
Teaching has become an important occupation in the changing society and has started to become a more eligible option in the decision making of individuals.

People build their career path with the help of various factors in different periods of their education. Secondary education level is the most concentrated period for this selection process. It is seen that students tend to settle for a career more and take the initiative at this stage (Deniz, 2001). The high school from which students have graduated at the secondary level is one of the factors affecting this choice. It can be seen in the studies conducted that students shape their career paths according to the type of high school graduated (Ay1k, Özdemir \& Yavuz, 2007). Students in Turkey who are in high school are generally young people between the ages of 14-18. According to Super (1957), students between the ages of 14-18 are in the experimental stage of the research phase of professional development. Students start their higher education after graduating from high schools, which charges their teachers with the responsibility to prepare them for the university. As a result, teachers experience the curriculum differently while facing various problems in the process. English language-oriented course (ELOC) is one of the popular fields that students choose in high school. The current study attempts to identify the opinions of ELOC teachers on the experienced curriculum, coursebook, and teaching methods.

\subsection{Literature review}

Turkish education system has witnessed various changes to transform into a more qualified version and catch up with the standards of the European Union. One of these changes is "Primary Education Law no. 6287" adopted on 30 March 2012, also publicly known as " $4+4+4$ ". It was a radical decision for the Turkish education system. With its application, 8 years of compulsory education was abolished and an extended version of 12 years of compulsory education came in force. This Law brought along changes regarding foreign language teaching, too. It was determined that the grade where foreign language education begins would be set to the $2^{\text {nd }}$ grade of primary schools and the number of English class hours in schedule was increased in high schools. The necessary steps were taken regarding the content regulation and school hours for foreign language education (MEB, 2012). Moreover, starting from 2012, the application of the weighted secondary school achievement score (AOBP) calculation was completely abolished and a new coefficient multiplication of 0.12 was introduced for all with the term 'secondary school achievement score'. With the new application, an equal score calculation method was adopted for each student in terms of the programs they wanted to go for at the university. Nevertheless, students continue to move towards a specific field with the 'optional course' item (10d) in Regulation on Secondary Education Institutions at the secondary level and add the courses of their choices to the curriculum they prefer to study for the academic year (Başbakanlık, 2013). Therefore, it seems clear that the removal of fields at secondary schools is not being applied in practice, which means the former regulation informally continues.

Another change to be put into practice is 'Turkey's Education Vision 2023' (MEB, 2018). With it, The Ministry of National Education (MoNE) has stated that they will pioneer the construction of a vision for the present and the future. Among the statements in this document, the one relates to high school is that English language skills will be taught through the "English for Specific Purposes" that will be developed primarily according to high school type. This model proposes that teaching methods will be shaped considering different language skills that are emphasized according to school and program types. For example, the vocational high schools of tourism and hotel management will focus more on listening and speaking skills while reading comprehension and presentation skills will be mainly emphasized in social sciences high schools (MEB, 2018). The idea of focusing on different skills according to the school types seems appealing but the fact that Anatolian high schools have got an ongoing field choice application and there is no regulation regarding their curriculum is worrisome for English teachers. 
ELOC is one of the fields students prefer to focus their studies on during high school education in the last 4 years of 12 years of compulsory education period. The students enter high schools according to their rank in the National High School Entrance Exam (LGS) and again they have a place in higher education through Higher Education Examination (YKS) depending on their rank. The fact that students participate in high stakes tests holds teachers responsible for the scores their students get. These tests have got influential impacts on teachers' teaching in terms of classroom activities/time, teaching materials, and teaching contents, teaching methods as well as their ways of assessing. The good image of the teachers depends on the success of students in the university entrance exam (Çetin \& Ünsal, 2019). The expectation to make students successful has become one of the teachers' professional roles. As defined by Y1ldirim (2011), this expectation is the real reason why the teaching profession turned into being a "technician teacher," which is a negative washback effect of university entrance exams.

It is difficult to say that teaching of foreign languages in Turkey brings about the desired success in high stakes tests. Many studies have focused on finding out what the problems might be regarding this failure (Bağçeci \& Yaşar, 2007; Işık, 2008; Haznedar, 2010; Paker, 2012; Oktay, 2014; Demirpolat, 2015; Yaman, 2018). In an international survey that attempts to rank countries accordingly with their Education First: English Proficiency Index (EF EPI) score, it was found that Turkey's English proficiency is in the very low competence range with 46,81 EF EPI. In additon, this finding puts Turkey in the 79th rank among 100 countries and 32nd rank among 33 European countries (EF EPI, 2019). In IELTS test statistics, Turkey has got a mean of 6.13 that places it in 26th rank out of 40 different native language speakers (IELTS, 2018). Hereby, the statistics for the English stage of the university entrance examination held by ÖSYM with different names of Undergraduate Placement Examination (LYS-5) and English Foreign Language Exam (YDT-English) will be depicted in Table 1. This finding is particularly significant for the study as the focus is on English teachers instructing ELOC students.

Table 1. Statistics of English Foreign Language Exams for university entrance held by ÖSYM

\begin{tabular}{cccc}
\hline Year & The name of the test $\begin{array}{c}\text { Average of correct } \\
\text { answers }(\%)\end{array}$ & $\begin{array}{c}\text { The number of total } \\
\text { participants }\end{array}$ & $\begin{array}{c}\text { The number of items } \\
\text { in the test }\end{array}$ \\
\hline LYS-5- English & 22,73 & 88.672 & 80 \\
\hline YDT- English & 24,824 & 101.185 & 80 \\
\hline & & & 106.363 \\
\hline
\end{tabular}

Source: (ÖSYM, 2017, 2018, 2019)

These are the mean numbers and correct answers of the students who have probably studied in ELOC (Students from other fields at high school are free to enter the English stage of the exam.) Considering there are 80 items in YDT, the mean for the correct answers seems quite low in number. The students who participate in YDT will possibly head towards higher education programs focusing on foreign languages and will continue taking other high stakes exams at some point.

Students start their higher education after graduating from high schools, which holds the teachers responsible for preparing students for the university. The fact that high schools need to achieve such a goal depends on their ability to provide their students with the necessary knowledge to score high from the university entrance exam as also defined in item number 10 of Regulation on Secondary Education Institutions (Başbakanlık, 2013). In a way, high schools are expected to educate their students and 
increase their level of readiness required for the university and the best predictor of the skills tried to be measured in the university entrance examination is the level of success achieved in high schools.

As mentioned before, many studies have focused on the challenges of English Language teaching, and some specifically focused on high schools (Demirel, 1979; Arslan, 2005; Kefeli, 2008; Yel, 2009; Aslantürk, 2011; Demirbulak, 2016; Erdem, 2016; Aksoy Tosun, 2018; Çarıkçığlu, 2018; Türkarslan, 2019). Yet, none has focused on ELOC and the challenges teachers face to prepare their students for higher education. This study hopes to establish an understanding of how the ELOC's curriculum is being applied in the $11^{\text {th }}$ and $12^{\text {th }}$ grades. Therefore, the results of the present study will be of great benefit to everyone related to the field in many ways considering that English has been and still is the most widely spoken and preferred language all around the world. First and foremost, it provides feedback about the implementation of the ELOC's curriculum of public Anatolian high schools in Antalya/Turkey. In other words, it provides feedback about how the implemented curriculum is planned and perceived by the English teachers as well as the challenges they face while teaching. As a result, the difficulties faced, suggestions made by the teachers, and the results taken after the implementation process are assumed to serve useful information for the program development specialists when they have future attempts to upgrade it.

\subsection{Research questions}

Based on the literature described so far, the present study seeks answers to the following research questions:

1. What are the opinions of English teachers in the English language-oriented course (ELOC) on the curriculum?

2. What are the opinions of English teachers in the English language-oriented course (ELOC) on coursebooks?

3. What are the opinions of English teachers in the English language-oriented course (ELOC) on the teaching methods used?

\section{Method}

The current study adopted a qualitative research design. As the primary target is to describe and not interfere, the single case study is preferred as it provides an opportunity for a holistic look (Gummesson, 2007).

\subsection{Participants}

The study was conducted with EFL teachers teaching $11^{\text {th }}$ and $12^{\text {th }}$-grade ELOC students. There were 17 public Anatolian High Schools in the five central districts of Antalya province at the time of data collection (Antalya Provincial Directorate of National Education, 2018), all of which were used as a research setting in this study. Students at Anatolian high schools do not officially choose a field anymore, which means there are not officially titled English language-oriented courses. Yet, they are formed according to the dynamics of each school, meaning MoNE cannot obtain the information and share it with the researchers through formal documents. Therefore, the researchers preferred a nonprobability sampling design; 'convenience design'. Although generalizing to a larger population was not the primary consideration in this study, to understand the intricacies of the sample and the topic deeply, the researchers have visited all the public Anatolian high schools in central Antalya instead of the available ones. 
The participants of the study consist of 31 English language teachers teaching $11^{\text {th }}$ and $12^{\text {th }}$-grade students in Anatolian high schools. Table 2 below shows their background characteristics to provide a deeper understanding of the content analysis of interviews.

Table 2. Background information of teacher participants

\begin{tabular}{|c|c|c|c|}
\hline Code of the Participants & Gender & Age & Year of Experience \\
\hline $\mathrm{T} 1$ & Male & 42 & 16 \\
\hline $\mathrm{T} 2$ & Female & 35 & 6 \\
\hline $\mathrm{T} 3$ & Female & 38 & 4 \\
\hline $\mathrm{T} 4$ & Female & 46 & 23 \\
\hline $\mathrm{T} 5$ & Female & 47 & 24 \\
\hline T6 & Female & 46 & 23 \\
\hline $\mathrm{T} 7$ & Female & 50 & 28 \\
\hline T8 & Male & 45 & 21 \\
\hline T9 & Male & 30 & 6 \\
\hline $\mathrm{T} 10$ & Female & 44 & 20 \\
\hline $\mathrm{T} 11$ & Female & 55 & 30 \\
\hline $\mathrm{T} 12$ & Female & 42 & 20 \\
\hline $\mathrm{T} 13$ & Male & 60 & 35 \\
\hline T14 & Female & 48 & 25 \\
\hline $\mathrm{T} 15$ & Female & 36 & 15 \\
\hline T16 & Female & 33 & 10 \\
\hline $\mathrm{T} 17$ & Female & 31 & 8 \\
\hline $\mathrm{T} 18$ & Female & 41 & 19 \\
\hline T19 & Female & 41 & 20 \\
\hline $\mathrm{T} 20$ & Female & 38 & 12 \\
\hline $\mathrm{T} 21$ & Female & 39 & 10 \\
\hline $\mathrm{T} 22$ & Female & 51 & 23 \\
\hline $\mathrm{T} 23$ & Male & 37 & 17 \\
\hline $\mathrm{T} 24$ & Female & 45 & 18 \\
\hline $\mathrm{T} 25$ & Female & 49 & 18 \\
\hline T26 & Female & 43 & 22 \\
\hline $\mathrm{T} 27$ & Female & 37 & 12 \\
\hline $\mathrm{T} 28$ & Male & 36 & 15 \\
\hline T29 & Female & 33 & 23 \\
\hline T30 & Male & 45 & 15 \\
\hline T31 & Female & 42 & 21 \\
\hline
\end{tabular}

Table 2 shows that $22.6 \%$ of teachers are male $(n=7)$ while $77.4 \%$ of them are females $(n=24)$, which makes 31 teachers in total. To represent all the views, teachers from different ages and years of experience are preferred in this research. The teacher participants' ages ranged from 30 to 60 years, and they had 4 to 35 years of teaching experience.

\subsection{Instrument}

In line with the scope of this research, a qualitative research design has been employed by the researchers to arrive at an understanding of the teachers' opinions. The one-on-one semi-structured interview is one of the most common data collection methods in qualitative research and a quite flexible and preferable way of asking people about their opinions and experiences (Harrell \& Bradley, 2009). The present study has been carried out by applying the 'Teachers' Interview Form'. Upon reviewing the literature and investigating the related studies, a semi-structured interview has been prepared by the researchers. The first section titled 'Personal Information' involves open-ended questions and items about the teachers' background characteristics such as age, gender, educational background, and experience. 
The validity of the items in the form was sustained in two ways: by expert opinion and pilot-testing. The actual items of the questionnaire, which were three in total, were derived from the pilot one-on-one in-depth interviews with three English language teachers from different Anatolian high schools in different districts and by receiving relevant expert opinions from three different faculty members in the faculty of educational sciences. The form was later piloted on these three teachers who were not included in the study to test the comprehensibility of the items. The final version of the interview form was shaped considering the pilot application and opinions of faculty members. The form itself was in Turkish and the interview was carried out in the Turkish language. The statements made by interviewees were later converted into written texts.

\subsection{Data collection procedures}

The present study was carried out in the second term of the 2018-2019 academic year, in the months of March-April-May. The second term was purposefully preferred as the teachers were about to complete teaching all the outcomes defined in the curriculum. All legal permissions were taken from MoNE prior to data collection. A schedule for visits was formed, and all the schools were asked to set a date for the interviews so that the teachers would be informed. The researchers informed the participants about the importance, purpose, and content of the study. After ensuring that the recording device was working well, the items in the questionnaire were directed carefully to confirm that all the interviewees would be relaxed and honest. Since teachers were low in number, the researchers completed the interviews by themselves to get the depth of detail from respondents. Although the questions were in order on the form, the teachers preferred to answer each question by connecting it to another question to form a reason-result relation. The completion of an interview took twenty-five minutes on average. Upon completing all the interviews, the researchers objectively transcribed the recorded statements within the scope of the subject.

\subsection{Data analysis}

Following the process of data collection, a descriptive analysis was applied in the way that was suggested by Yildırım and Şimsek (2006). Because there was no purpose in this study to interfere or relate thoughts with each other but rather describe the existing situation, descriptive statistics; frequency distributions were calculated.

To analyse the qualitative data obtained from the interviews and open-ended questions, first of all, a frame where the data were given codes under named themes by considering the research questions and the sections in the form was created. As the themes were pre-determined, attention was given to make the identified codes place in the suitable themes. After that, with computations that were made, all the coded data under thematic categories were converted into frequencies and percentages. The data that are related to each open-ended item and obtained from each group of participants were displayed in separate tables. The emerged codes were stated in a descending order from the most to the least common and the percentages of them were presented after calculation. Lastly, the results were defined by referring to direct quotations. Only the statements that were significant and noteworthy were directly added at the end of the analysis to further picture the respondents' thoughts.

\section{Results}

Opinions of teachers collected through the 'Teachers' Interview Form' are going to be depicted in a detailed way in this section. The discussion of the findings is made within the scope of the research 
questions and presented separately under relevant sub-sections. In this section, a summary of the problems faced in the curriculum is also going to be presented.

\subsection{Findings of the items regarding Research Questions}

Although the items in the form have been planned to ask separately, the teachers preferred to answer all three of them by linking to each other. During the flow of the semi-structured interview, the researchers decided not to stop them as the concepts of 'curriculum', 'coursebooks' and 'teaching methods' are closely connected in teaching. Therefore, regarding the research questions of the study, the participant teachers were asked to talk about their formal curriculum provided by the MoNE and their actual applications of the curriculum in detail (the number of the each subject matter provided in the curriculum, planned materials for ELOC, recommended teaching methods, learning outcomes, the number and the style of examination, etc.). After a thorough analysis of their responses, themes of 'Teaching methods', 'Curriculum in general', 'Other sources of coursebooks', 'The number of the English courses' and 'Recommendations' were determined. All the mentioned themes and their codes have been stated with the number of their frequency in Table 3 below.

Table 3. Opinions of teachers on curriculum, coursebooks and teaching methods

\begin{tabular}{|c|c|c|c|}
\hline Sub-Theme & Codes & $\begin{array}{l}\text { Participants' } \\
\text { information }\end{array}$ & Frequency \\
\hline \multirow{8}{*}{$\begin{array}{l}\text { Teaching } \\
\text { methods }\end{array}$} & I focus mainly on grammar. & $\begin{array}{l}\text { T1, T2, T4, T5, Т6, T9, } \\
\text { T10, T17 T18, T19, T20, } \\
\text { T21, T22, T23, T24, T25 }\end{array}$ & 16 \\
\hline & $\begin{array}{l}\text { My focus is on the university } \\
\text { entrance examination. }\end{array}$ & $\begin{array}{l}\text { T2, T4, T5, T6, T9, T13, } \\
\text { T19, T20 T22, T24, T25, } \\
\text { T29, T31 }\end{array}$ & 13 \\
\hline & I do not focus on skills. & $\begin{array}{l}\text { T2, T4, T5, T6, T10, T19, } \\
\text { T20, T22, T29, T30 }\end{array}$ & 10 \\
\hline & $\begin{array}{l}\text { I do not teach literature in Literature } \\
\text { course. }\end{array}$ & $\begin{array}{l}\mathrm{T} 1, \mathrm{~T} 2, \mathrm{~T} 10, \mathrm{~T} 16, \mathrm{~T} 15, \mathrm{~T} 17 \\
\mathrm{~T} 19, \mathrm{~T} 20\end{array}$ & 8 \\
\hline & $\begin{array}{l}\text { I focus mainly on pilot university } \\
\text { entrance examinations }\end{array}$ & $\mathrm{T} 1, \mathrm{~T} 19$ & 2 \\
\hline & $\begin{array}{l}\text { I am elective depending on my } \\
\text { students' needs. }\end{array}$ & T8, T29 & 2 \\
\hline & $\begin{array}{l}\text { I assign my students with specific } \\
\text { and periodic homework. }\end{array}$ & $\mathrm{T} 24, \mathrm{~T} 25$ & 2 \\
\hline & $\begin{array}{l}\text { I try to teach the subjects repeatedly } \\
\text { for my students not to forget. }\end{array}$ & $\mathrm{T} 10$ & 1 \\
\hline \multirow{2}{*}{$\begin{array}{l}\text { Curriculum in } \\
\text { general }\end{array}$} & I develop/adapt my curriculum. & $\begin{array}{l}\text { T1, T2, T7, T10, T13, } \\
\text { T19 }\end{array}$ & 6 \\
\hline & $\begin{array}{l}\text { There is no ELOC curriculum } \\
\text { offered by the MoNE. }\end{array}$ & $\begin{array}{l}\text { T1, T3, T9, T13, T14, T24, } \\
\text { T25, T31 }\end{array}$ & 8 \\
\hline \multicolumn{4}{|l|}{$\begin{array}{c}\text { Table } 3 \\
\text { continued }\end{array}$} \\
\hline \multirow{3}{*}{$\begin{array}{c}\text { Another } \\
\text { source of } \\
\text { coursebooks }\end{array}$} & $\begin{array}{l}\text { The coursebooks provided by } \\
\text { MoNE is inefficient. }\end{array}$ & $\begin{array}{l}\text { T2, T10, T14, T17, T15, } \\
\text { T16, T19, T24, T25, T26, } \\
\text { T27, T28, T31 }\end{array}$ & 13 \\
\hline & $\begin{array}{l}\text { I must use other sources of } \\
\text { coursebooks as my students prefer } \\
\text { them. }\end{array}$ & $\begin{array}{l}\mathrm{T} 1, \mathrm{~T} 8, \mathrm{~T} 15, \mathrm{~T} 16, \mathrm{~T} 17 \\
\mathrm{~T} 26, \mathrm{~T} 27, \mathrm{~T} 28, \mathrm{~T} 29, \mathrm{~T} 30\end{array}$ & 10 \\
\hline & I must create my coursebook. & $\begin{array}{l}\text { T14, T25, T26, T27, T28, } \\
\text { T29 }\end{array}$ & 6 \\
\hline
\end{tabular}




\begin{tabular}{|c|c|c|c|}
\hline $\begin{array}{l}\text { The number } \\
\text { of English } \\
\text { courses }\end{array}$ & $\begin{array}{l}\text { The number of English courses is } \\
\text { not enough. } \\
\text { The number of English courses is } \\
\text { enough. }\end{array}$ & $\begin{array}{l}\text { T1, T2, T10, T19, T24, } \\
\text { T25, T29, T31 } \\
\text { Т11, T12, Т22, T26, T27, } \\
\text { T28 }\end{array}$ & 6 \\
\hline \multirow{8}{*}{ Suggestions } & $\begin{array}{l}\text { The students should decide which } \\
\text { department they want to study in } \\
10^{\text {th }} \text { grade }\end{array}$ & $\begin{array}{l}\text { T2, T3, T4, T5, T6, T7, } \\
\text { T11, T12, T13, T15, T16, } \\
\text { T19, T21, T26, T29, T30, } \\
\text { T31 }\end{array}$ & 17 \\
\hline & $\begin{array}{l}\text { The MoNE should provide } \\
\text { specifically designed ELOC } \\
\text { coursebooks. }\end{array}$ & $\begin{array}{l}\mathrm{T} 1, \mathrm{~T} 2, \mathrm{~T} 20, \mathrm{~T} 22, \mathrm{~T} 25, \\
\mathrm{~T} 26, \mathrm{~T} 27, \mathrm{~T} 28, \mathrm{~T} 29, \mathrm{~T} 31\end{array}$ & 10 \\
\hline & $\begin{array}{l}\text { The MoNE should provide us with } \\
\text { an appropriate curriculum developed } \\
\text { for ELOC. }\end{array}$ & $\begin{array}{l}\text { T4, T5, T6, T7, T13, T20, } \\
\text { T26 }\end{array}$ & 7 \\
\hline & $\begin{array}{l}\text { The MoNE should let us order } \\
\text { another source of coursebooks. }\end{array}$ & $\mathrm{T} 3, \mathrm{~T} 4, \mathrm{~T} 5, \mathrm{~T} 6, \mathrm{~T} 12$ & 5 \\
\hline & $\begin{array}{l}\text { If the curriculum will be re- } \\
\text { developed, teachers' opinions } \\
\text { should be taken. }\end{array}$ & $\mathrm{T} 11, \mathrm{~T} 19, \mathrm{~T} 26, \mathrm{~T} 27, \mathrm{~T} 28$ & 5 \\
\hline & $\begin{array}{l}\text { A series of coursebooks designed } \\
\text { for ELOC should be provided by the } \\
\text { MoNE }\end{array}$ & T9, T10, T13, T19 & 4 \\
\hline & $\begin{array}{l}\text { At least } 2 \text { teachers should teach } \\
\text { ELOC at the same time by sharing } \\
\text { English courses. }\end{array}$ & $\mathrm{T} 18, \mathrm{~T} 26, \mathrm{~T} 29, \mathrm{~T} 30$ & 4 \\
\hline & $\begin{array}{l}\text { In } 12^{\text {th }} \text { grade, students should be } \\
\text { directed to solve multiple-choice } \\
\text { questions to score better in } \\
\text { university examination. }\end{array}$ & $\mathrm{T} 1, \mathrm{~T} 3$ & 2 \\
\hline
\end{tabular}

Upon examination of Table 3, the opinions of teachers about the teaching methods and curriculum of the ELOC were summarized under 5 themes. Accordingly, the teachers who expressed their thoughts under the theme of 'teaching methods' recurring 54 times outbalanced under this theme.

Our findings have revealed that the teachers do not follow the teaching methods coherent with the curriculum provided by the MoNE. When the codes in the theme of the 'Teaching methods' were analysed, it was visible that the most repetitive codes were 'I focus mainly on grammar' and respectively, 'My focus is on university entrance examination.', 'I don't focus on skills.', 'I don't teach Literature in Literature courses.' and others. When the codes in the 'Another source of coursebooks' theme were examined, the most repetitive codes were 'The coursebooks provided by MoNE is inefficient', 'I must use other sources of coursebooks as my students prefer them' and lastly 'I must create my coursebook.'.

When the codes in the theme of 'the number of English courses' were examined, it was detectable that the teachers were nearly split into two groups with disagreement. The most repeated codes were 'The number of English courses is not enough.' with 8 times and 'The number of English courses is enough.' with 6 times. After the codes in the theme of 'Suggestions' were examined, the most repetitive codes showed that teachers mostly agreed on the fact that the students should select which department they want to study in $10^{\text {th }}$ grade instead of $11^{\text {th }}$ grade. Also, they stated that 'MoNE should provide specifically designed ELOC coursebooks.', 'MoNE should provide us with an appropriate curriculum designed for ELOC.', 'MoNE should let us order another source of coursebooks.', 'If the curriculum will be re-designed, teachers' opinions should be taken.' and others. In brief, it was clear that a considerable number of teachers would like to have a complete change in curriculum and coursebooks.

Some views of the codes in the themes were expressed in detail as follows: 
Stating that 'the curriculum' should be elaborated, and that 'the curriculum' is not suitable for ELOC, T1 also stated that MoNE should do something in terms of other sources of coursebooks and reference books by uttering these words:

"... It is not possible to focus on other skills defined in the curriculum as we can only aim the best score for the university exam. Our students would rather buy other sources of coursebooks than coursebooks provided by the government as they do not find them relevant to their studies. I am trying to do my best to help them guide their studies with those coursebooks too as this is their request. We are doing the yearly plan with my students by negotiation at the beginning of the year. We try to stick with the current provided curriculum. Yet, I also try to respect my students' choices of using another source of coursebooks while planning the educational year. ... Though we must assess our students with regular exams aiming to reveal the achievement of the curriculum, our students are preparing themselves for a test that includes multiple-choice grammar-based questions, which means we are contradicting ourselves. The MoNE should do something in terms of resources and coursebooks." (T1)

Stating that a mostly Grammar-based course is being taught, T2 also asserted that the number of ELOC hours should be increased and that field selection should be taken back to the $10^{\text {th }}$ grade again.

“... Based on any existing English curriculum provided by the MoNE, we are adapting our curriculum to be applied in English language-oriented course. Of course, we are having difficulty in adapting it as we do not have enough time or the motivation to focus on skills. As the books submitted for this curriculum did not serve the exam, my students wanted to employ other resources to prepare for the university entrance examination. ... As my students complain all the time how behind the planned schedule they are, the main objective during both the planning and the courses is always on mastering English grammar. Therefore, I assume I always teach my lessons with the aim of exam preparation as it serves more to the students. As a result, we are ignoring the importance of skills emphasized in the actual curriculum. It is like we have an exam ahead us for which we need to run as fast as we can. Having an increase in the number of English courses would make it much easier. Also, having other resources for teaching would be more fruitful for my students..." (T2)

Stating that the number of English courses is enough and if a new curriculum possibly is going to be designed, teachers' opinions should be taken, T11 spoke as follows:

"The number of English lessons (15 hours) is more than enough. If we had more courses with them, our students would be tired out and bored of us. I completely agree with my friends that taking the opinions of the teachers is important for a real and functioning curriculum. Additionally, such applications we had before as having English preparatory courses at the beginning of high school education and choosing a field at the end of $9^{\text {th }}$ grade should be brought back to the agenda again." (T11)

Criticizing about not having a specifically designed curriculum for ELOC, T10 and T13 indicated their expectation of having a new coursebook and curriculum designed specifically for them by MoNE by stating the following:

“...The coursebooks provided by MoNE are coherent with the curriculum but completely irrelevant to the examination for university entrance. How can I employ the curriculum and the coursebook provided when my students are completely demotivated? As a result, we design and plan our curriculum by sticking to the functions of MoNE. I cannot teach British Literature subjects, either. As studying in ELOC or any other field has become optional, we cannot always have enough hours of courses for English. Lastly, I must mention the need for a new coursebook designed only for ELOC." (T10)

“... MoNE does not serve us with a specifically designed ELOC curriculum. The university entrance examinations: especially English, do not evaluate the four skills as defined in CEFR (The Common European Framework of Reference for Languages) and our current curriculum. That is why we must 
put other resources published with the aim of university entrance exam preparation into use. As English teachers, we are developing a new curriculum by planning out all two years, $11^{\text {th }}$ and $12^{\text {th }}$ grades. There should be a change with the timing of field selection, too. While all my friends are using what is provided by MoNE, I have to re-plan, re-develop, and put so much thought into what I am going to do in all two years for my students. I hope there will be a change soon." (T13)

Defending that MoNE should enter an agreement with private publishing companies, thereby provide ELOC with better resources, T20 also suggested that ÖSYM should start measuring all four skills defined by CEFR and the curriculum. T20 stated as follows:

"We have got 14 hours of English courses. Generally, the focus is on teaching grammar, which is essential for the university exam. There should be an agreement with a private publishing company for more resources. The only thing my students are requesting is to solve multiple-choice questions every day. I cannot be expected to emphasize the four skills defined in the curriculum while they are not assessed in the university entrance examination. I would prefer one teacher for all 14 hours as the students tend to compare both teachers, which causes unease. Lastly, I would like to have an actual yearly and daily plan ready for use and published on EBA." (T20)

Other views regarding the themes were stated as follows:

"This is a dilemma. We have the book sent to us by MoNE. The students have other books that they want to buy as it serves to them more. We would like to stick up with the curriculum. Whereas the students prefer to solve multiple-choice questions. Classroom teaching by and large is in students' native language (Turkish) while the courses are English-oriented. I do not know what to say about this. At least they had better bring back the former regulation of choosing a field at the beginning of $10^{\text {th }}$ grade. This way we can load our students with more grammar and techniques for the university entrance examination." (T30)

"What we try to achieve here is to get the students to be prepared well for the university entrance exam. This is the definition of being a favourable teacher for my students now. I start teaching a class when they are in $11^{\text {th }}$ grade and first handle the grammar part quickly. With loads of revision and assessment, I am dividing months into the weeks by focusing on the grammar subjects. Also, I am trying to focus on the special techniques of solving different types of multiple-choice questions. All the teaching aims to be successful at the university exam. ...The other thing I want to mention here is that as we are not allowed to use any resources that are not provided by MoNE, we expect them to send us some quality resources for use." (T4)

"Our priority is on the English part of the university entrance examination. In this exam, the types and content of the questions tend to change every year. This means a constant change with your plans and a continuous preliminary preparation. Not everyone volunteers to teach ELOC as it also means a continuous process of preparing your material. I am not sure if MoNE is going to do anything about it, but this is the system we are in right now." (T14)

"I try to organize myself and create materials and resources for my students. Yet, it is not always enough because the students want to solve as many questions as possible to get prepared for the exams. Therefore, they order some other resources and bring them to class to ask me to explain all the subjects and questions they could not understand. Having a curriculum irrelevant to the current exam system, I have no other choice but to use the resources my students provide me with. There is a necessity for an effective and relevant to the exam coursebook and other resources. Some time ago, we have had English preparatory courses. It was truly blissful. (T25) 


\section{Discussion}

This study explored the opinions of ELOC teachers on the curriculum they experienced throughout the 2018-2019 academic year. In this section, to attain the answers to the research questions, the literature review and the findings revealed in the previous section were referred to.

\subsection{Opinions on curriculum}

In the light of the data above, the teachers were asked why they do not prefer to use the provided current curriculum. Then, they clearly stated that the students want their studies to focus mostly on the subjects existing in the university entrance examination. Therefore, it was clear that teachers were having difficulty in implementing the available curriculum since the students were reluctant to learn any other subject matter that is not assessed in the university entrance examination. From this point of view, it can be said that teachers require flexibility in choosing what subject matters they think the students benefit from the most. In addition, the results in this study surprisingly revealed that when teachers referred to their curriculum, they thought it as the annual plans and the coursebooks.

As stated in the English curriculum for Secondary schools, the $9^{\text {th }}-12^{\text {th }}$ grade English curriculum was designed under the descriptive and pedagogical principals of CEFR. On the other hand, the students are going to participate in the university examination, the second stage of which will be in the English language. The teachers indicated that the university exam selects students according to how good of a grammar command they own.

The present findings confirmed that teachers were not content with the present curriculum. This finding appears quite consistent with Çarıkçığlu's study (2018) on perceptions of teachers and students on the high school English curriculum. In her study, she also confirmed that the teachers found the current curriculum for $9^{\text {th }}$ to $12^{\text {th }}$ grades inefficient and the curriculum needs more development by considering the faced problems.

The findings also partially agreed with Ersen-Yanık's MA (2007) thesis. The present study also revealed that teachers were not happy with curriculum implementation due to certain factors that could be divided into categories: school-level factors, coursebook(s), students, the curriculum itself, and the classroom environment.

Based on the results, it can be stated that the teachers lack confidence in the present curriculum. This affects their desire to teach in different ways. The same finding can be seen in Kefeli's study (2008). She stated that neither students nor teachers believe English can be learned with such a curriculum, which resulted in a lack of confidence in the current program.

Students who answer a certain part of the questions correctly in the university entrance examination can be placed in the higher education programs they wish to enrol (Gurbuzturk, \& Kincal, 2018). The teachers honestly stated that their biggest source of demotivation is the contradiction between school exams and university entrance examination. This contradiction forced them to accept/ask for grammarbased teaching instead of the communicative method defined in the curriculum and coursebook.

Other two codes under the theme of 'Suggestions' were "MoNE should provide us with an appropriate curriculum designed for ELOC.", and "If the curriculum will be re-designed, teachers' opinions should be taken.". This indicates that teachers are looking for ways of finding a solution to their curriculum-related problems. Lastly, the participants emphasized the importance of involving teachers actively in curriculum development. 


\subsection{Opinions on coursebook}

According to the results obtained in this research, similar problems with the experienced curriculum came up since the coursebooks did not meet the criteria in the literature. In addition, they were not able to meet the expectations of the teachers in the language teaching and learning process. Initially, $69 \%$ of the teachers stated they were okay with the coursebooks, but then they clarified themselves by uttering that they were not allowed to use any other source of coursebooks. The idea in common is that it affects the learning process negatively. These findings point out that teachers need a new source of coursebook. $93 \%$ of the teachers asserted that they were dealing with the stress of creating the best source of class material for their students as the coursebook provided by MoNE was reported not to be emphasized in the current university entrance examination.

The results of Kefeli's study (2008) are correspondent with the present study. The materials provided by MoNE were lacking to practise student-centred lessons. Therefore, insufficient materials resulted in more workload on the shoulders of the teachers. In the present study, teachers expressed that they prepared extra materials almost every school day for the students as they believed it was better when students solved multiple-choice questions from different publishing houses. Another fact revealed was that teachers tended to equate their students' success with themselves, which resulted in putting more effort into preparing materials to motivate students. It was promising to see that while forming or choosing a substitute for the coursebooks, the teachers offered students opportunities to participate in the decision process. In the literature, Weimer (2002) suggests that if students are engaged, involved, and connected with a class, they feel motivated to work harder, and working harder on task results in more learning.

Lastly, we found out that none of the teachers found the coursebooks fit for use and that additional or alternative resources were needed. This result confirmed the findings of Çarıkçığlu (2019). She concluded that since the same coursebooks were sent to all types of High schools (Social sciences high school, Anatolian high school, Vocational-technical high schools, etc.), the needs of students were completely neglected. Thus, it is clear from both studies that a single type of coursebook cannot be used to teach all types of high schoolers.

\subsection{Opinions on teaching methods}

After a closer look at the theme 'Teaching methods' extracted from teachers' interviews, it can be understood that the teachers do not follow the teaching methods coherent with the curriculum provided by MoNE. When the codes with the theme of the 'Teaching methods' in interview were analysed, the most significant point to be focused was that although the curriculum provided by the MoNE focuses mainly on skills as designed according to CEFR, the teachers clearly stated that they cannot focus on skills as the university entrance examination is completely different. That difference mainly arises from the fact that reading is the only skill that is assessed in university entrance exam though CEFR serves as a reference point that mainly focuses of describing the levels of proficiency skills as well as providing context for test content. To further understand this issue, the codes in the theme of 'Curriculum in general' were examined. It can be concluded that the teachers are affected by their students who want their studies to focus mostly on the subjects existing in the university entrance examination. Therefore, students' refusal to learn any subject matter taking part in the curriculum but not assessed in the university entrance exam plays a vital role in teachers' decisions. Teachers also stated that the nature of university entrance exam has been influential on their assessment ways and content, which can be a negative washback effect in terms of assessment. These teachers generally preferred to ignore the CEFR standards and stick to the only skill to be evaluated during university entrance exam. Çetin and Ünsal, (2019) revealed that two teachers asserted central examinations negatively affected their personal and 
professional development. It was underlined that central examinations prevented them from socializing and robotized them. Similarly, these examinations were increasing the teachers' workload.

\section{Conclusions}

To conclude, first and foremost, more studies are needed on the issues investigated in order to emphasize and draw attention to these problems. It is highly obvious that English teachers working in ELOC in Anatolian High schools in Central Antalya have faced various challenges regarding the curriculum, coursebook, and the teaching methods defined. The process of developing a top-down program does not allow all the stakeholders to be involved in the process. Although the present curriculum consists of all four skills and is mainly based on communicative teaching methods, the university entrance examination does not involve questions regarding the defined skills of listening, speaking, and writing in language teaching and CEFR. The fact that reading is the solely targeted skill to be assessed during university entrance examination causes confusion and complexity among the teachers and students. There is an emergent necessity for this confusion to end with a common act planned and put into action by MoNE and YÖK (Council of higher Education).

Secondly, it is clearly shown that the implementation and application of CEFR within the curriculum of English language oriented classes is not without its challenges and does not automatically lead to success as the assessment stage of it is still linked to university entrance exam which only measures reading based skills. On the other hand, most of the language exams in Europe are developed in a way that its scores can be related to CEFR by focusing on CEFR descriptors for levels of proficiency skills. Another aspect that is revealed is that the curriculum suggests an eclectic approach for teachers by combining the use of communicative language teaching method and student-centred methods in line with CEFR. Yet, there are various practises of assessment that are neither communicative nor student centred and the final assessment for the university entrance is the reason behind it. As Cephe and Toprak (2014) also concluded, a test development model for university entrance exam which will help and guide teachers in defining the constructs, generating the test, administrating and evaluating it by considering all the context would result in practical implications. This model is suggested to be formed by collaborative work of MoNE and YÖK.

Lastly, using the same curriculum for all types of high schools and being partly or mostly irrelevant to the university entrance exam causes a lot of challenges to teachers and students. It was also revealed in the study that the same books designed by MoNE were sent to all Anatolian high schools and all fields. The students in different fields have different schedules where the number of English courses and class hours also differs. Therefore, the same book cannot meet the needs of the students in all the fields. Moreover, these books are aligned with CEFR principles though the national university entrance examination has got its independent construct and content. High stakes tests have been and still are the most influential source of washback effect on teaching and learning. Thus, MoNE is suggested to first take a step by conducting a needs analysis in Turkey by integrating all the stakeholders in the process by taking CEFR into consideration. Then, the curriculum of ELOC and teaching materials should be redesigned accordingly, which will result in a change in assessment.

\section{Ethics Committee Approval}

The author confirms that ethical approval was obtained from Akdeniz University (Approval Date: 04/02/2019). 


\section{References}

Aslantürk, S. (2011). Anadolu liselerinde kullanılan yeni İngilizce öğretim programı ve ders kitapları hakkında ögretmen görüslerinin belirlenmesi, Zonguldak ili örneği. (Unpublished master's thesis). Zonguldak Bülent Ecevit University, Zonguldak.

Ayık, Y. Z., Özdemir, A. \& Yavuz, U. (2007). Lise türü ve mezuniyet başarısının kazanılan fakülte ile ilişkisinin veri madenciliği tekniği ile analizi. Atatürk Üniversitesi Sosyal Bilimler Enstitüsü Dergisi. $10(2), 441-454$.

Bağçeci, B., \& Yaşar, M. (2007). Opinions of students attending high schools in Gaziantep about the teaching of English. Gaziantep University Journal of Social Sciences, 6(1), 9-16.

Başbakanlık. (2013). Regulation on secondary education institutions. Official Gazette, No: 28758. Retrieved from https://www.resmigazete.gov.tr/eskiler/2013/09/20130907-4.html

Cephe, P. T., \& Toprak, T. E. (2014). The common European framework of reference for languages: Insights for language testing. Journal of Language and Linguistic Studies, 10(1), 79-88.

Çarıkçığlu, M. (2018). 2018 ortaöğretim İngilizce dersi öğretim programının uygulanmasında karşılaşılan sorunlara ilişkin ögretmen ve öğrenci görüşleri. (Unpublished master's thesis). Hacettepe University, Ankara.

Çetin, A., \& Ünsal, S. (2019). Social, psychological effects of central examinations on teachers and their reflections on teachers' curriculum implementations. Hacettepe University Journal of Education, 34(2), 304-323.

Demirbulak, D. (2016). Anadolu öğretmen lisesi öğrencilerinin İngilizce dersindeki uygulamalara ve öğretmenliğine ilişkin düşünceleri, İngilizce öğretmenlerinin konuya ilişkin yorumları ve program geliştirmede uzlaşmacı yaklaşım. Kastamonu Eğitim Dergisi, 21(4), 1641-1660.

Demirel, Ö. (1979). Ortaögretimde yabancı dil ĕgitim programlarının değerlendirilmesi. (Unpublished doctoral dissertation). Ankara University, Ankara.

Demirpolat, B. C. (2015). Türkiye'nin yabancı dil öğretimiyle imtihanı: Sorunlar ve çözüm önerileri. SETA. Retrieved from http://file.setav.org/Files/Pdf/20150707131308_131_yabancidil_web.pdf

Deniz, S. (2001). Bireyin meslek seçimini etkileyen kaynaklar: Yeni teknolojilerden internet. Muğla Üniversitesi Sosyal ve Beşeri Bilimler Araştırmaları Dergisi, 6, 1-9.

Erdem, S. (2016). Ortaokul-lise ögrrencilerine ve İngilizce ögretmenlerine göre İngilizce ögretiminde karşılaşılan sorunlar. (Unpublished master's thesis). Sakarya University, Sakarya.

Ersen-Yanık, A. (2007). Study of English language curriculum implementation in 6th, 7th, and 8th grades of public primary schools through teachers' and students' perceptions. (Unpublished master's thesis). Middle East Technical University, Ankara.

Gummesson, E. (2007), Case study research and network theory: Birds of a feather, qualitative research in organizations and management. An International Journal, 2(3), 226-248.

Gurbuzturk, O. \& Kincal, R. Y. (2018). Türkiye'de yükseköğretime geçiş sürecinin analizi: gelişmeler, modeller ve uygulamalar. Akdeniz Ĕgitim Araştırmaları Dergisi, 12(24), 33-54.

Harrell, M. \& Bradley, M. (2009). Data collection methods: Semi-structured interviews and focus groups. Rand, National Defense Research Institute, USA. 
Haznedar, B. (2010). Türkiye'de yabancı dil eğitimi: Reformlar, yönelimler ve öğretmenlerimiz. International Conference on New Trends in Education and their Implications, 11-13 Kasim, 2010, Antalya.

Işık, A. (2008). Yabancı dil eğitimimizdeki yanlışlar nereden kaynaklanıyor. Journal of Language and Linguistic Studies, 4(2), 15-26.

IELTS, (2018). Test Statistics. Retrieved June 20, 2020 from https://www.ielts.org/research/teststatistics

Kefeli, H. (2008). Exploring the perceptions of teachers, students, and parents about the new 4-year Anatolian high school English program. (Unpublished master's thesis). Middle East Technical University, Ankara.

MEB (MoNE). (2018). Turkey's Education Vision. Retrieved from https://2023vizyonu.meb.gov.tr/doc/2023_VIZYON_ENG.pdf

Oktay, A. (2015). Foreign language teaching: A problem in Turkish education. Procedia - Social and Behavioral Sciences, 174. 584-593.

ÖSYM (2017). 2017-ÖSYS yerleştirme sonuçlarına ilişkin sayısal bilgiler. Retrieved from https://dokuman.osym.gov.tr/pdfdokuman/2017/OSYS/YER/YSay\%C4\%B1sal\%20Bilgiler150820 17.pdf

ÖSYM (2018). 2018-YKS değerlendirme raporu. Retrieved from https://dokuman.osym.gov.tr/pdfdokuman/2018/GENEL/YKSDegrapor06082018.pdf

ÖSYM (2019). 2019-YKS Sınav Sonuçlarına İlişkin Sayısal Bilgiler. Retrieved from https://www.osym.gov.tr/TR,16859/2019-yks-sinav-sonuclarina-iliskin-sayisal-bilgiler.html

Paker, T. (2012). Türkiye'de neden yabancı dil (İngilizce) öğretemiyoruz ve neden öğrencilerimiz iletişim kurabilecek düzeyde İngilizce öğrenemiyor. Pamukkale University Journal of Education, 32. 89-94.

Super, D. E. (1957). The psychology of careers: An introduction to vocational development. New York, Harper, and Row Publishers.

Taşl1, F. (2003). İlköğretimde İngilizce Öğretiminde Oyun Tekniğinin Erişiye Etkisi. (Unpublished master's thesis). Niğde University, Niğde.

Türkarslan, D. (2019), Ortaögretim İngilizce dersine yönelik ögrenci tutumlarının ve öğretmen görüşlerinin belirlenmesi. (Unpublished master's thesis). Zonguldak Bülent Ecevit University, Zonguldak.

Yaman, İ. (2018). Türkiye'de İngilizce öğrenmek: Zorluklar ve firsatlar. RumeliDE Dil ve Edebiyat Araştırmaları Dergisi, (11), 161-175.

Yel, A. (2009). Evaluation of the effectiveness of English courses in Sivas Anatolian High School. (Unpublished master's thesis). Middle East Technical University, Ankara.

Yıldırım, A. \& Şimşek H. (2006). Sosyal bilimlerde nitel araştırma yöntemleri. Ankara: Seçkin Yayincilik.

Yıldırım, A. (2011). Öğretmen eğitiminde çatışma alanları ve yeniden yapılanma. Uluslararası Eğitim Programları ve Ögretim Çalışmaları Dergisi, 1(1), 1-17. 
Weimer, M. (2002). Learner-centered teaching: Five key changes to practice. San Francisco, CA: Jossey-Bass.

\section{İngilizce dil sınıfında İngilizce öğretmeni olmak}

\section{$\ddot{O ̈ z}$}

Milli Eğitim Bakanlığı tarafından hazırlanan 11. ve 12. kademe İngilizce dil sınıfları odaklı derslerin müfredatı (ELOCC) üzerinde yoğun olarak odaklanılmayan bir konudur. 11 ve 12. Sınıflar için hazırlanan müfredatın kendisi kapsamlı bir şekilde planlanmış olmasına rağmen, dil sınıflarına özgü olmaması nedeniyle öğretmenlerin uygularken karşılaştıkları bazı zorluklar bulunmaktadır. Bu çalışmada, uygulanan müfredatın öğretmenler tarafindan nasıl algılandığı ortaya konulmuştur. Araştırma grubunu, Antalya'da İngilizce dil bölümü olan Anadolu liselerinde dil sınıflarında derse giren 31 İngilizce öğretmeni oluşmaktadır. Araştırma nitel bir yöntemle yürütülmüştür. Veriler, öğretmenlerden araştırmacı tarafından yönetilmiş yarı yapılandırılmış görüşmeler yoluyla toplanmış ve daha sonra içerik analizi ile incelenmiştir. Görüşme maddeleri araştırma soruları ile uyumludur. Başlıca araştırma alanları, öğretmenlerin genel müfredat uygulaması, ders kitapları ve kendi öğretim yöntemleri hakkındaki düşüncelerinden oluşmaktadır. Çalışma süresince bu konunun derinlemesine ortaya konması amaçlanmıştır. Çalışmanın sonunda, İngilizce dil odaklı derslerin müfredatının nasıl uygulandığına dair bir anlayış oluşmuştur. Öğretmenlerin neredeyse tamamının genel olarak müfredat uygulamasından, ders kitapları ve tercih edilen yöntemlerden memnun olmadığı sonucuna varılmıştır. Öğretmenlerin çoğu, üniversiteye giriş sınavının yöntem ve uygulanan müfredata doğrudan etki ettiğine ve bunun da ders kitaplarının uygulanmasının reddedilmesine neden olduğuna dikkat çekmiştir. Elde edilen sonuçlar dikkate alınarak, müfredat, ders kitabı ve yöntem konularını kapsayan bazı önerilerde bulunulmuştur.

Anahtar kelimeler: İngilizce dil sınıfı müfredatı; İngilizce dil sınıfları; İngilizce dil sınıfı ders kitapları; öğretim yöntemleri; İngilizce dil sınıflarındaki sorunlar; İngilizce öğretmenlerinin yaşadığı sorunlar

\section{AUTHOR BIODATA}

Özge BAKAY is a full time English language expert in Digital Content Commission of MoNE, Directorate of Antalya. She has been working as an English teacher in MoNE for 7 years. She is keen on the fields of Digital Content Creation, English Language Teaching, CALL, Testing in ELT and Bilingualism.

Dr. F. Özlem Saka is a full-time lecturer at Akdeniz University, Faculty of Education, ELT Department, Antalya, Turkey. She has been working at university for about 33 years. She is interested in the fields of English Language Teaching, Literature Teaching in ELT, Testing in ELT and Language Teacher Training. 